Article Type: Research Paper

\title{
Poverty Analysis and Inequality Distribution in Yogyakarta Special Region
}

\author{
Yulian Anshita Dewi ${ }^{1}$ and Dessy Rachmawatie ${ }^{1}$
}

\begin{abstract}
This study aims to analyze Poverty Inequality and Inequality of Regency/ City Revenue Distribution in Yogyakarta Province D.I. Secondary data here uses data between places or spaces (cross-sections) taken from all districts/cities in Yogyakarta, while data for time series data is taken in 2009-2015 where this data is data collected in a certain time period. Data which is a combination of crosssection and time-series data used in this study is called panel data. The paper using literature review approach and metadata analysis. In this study, the results show that the human development index variable, GRDP, local original income, general allocation funds affect the Inequality of the District Revenue / City Distribution in Yogyakarta.

Keywords: Poverty; Inequality of Income Distribution; GRDP; Regional Original Income; General Allocation Fund.
\end{abstract}

${ }^{1}$ Department of Economics, Faculty of Economics and Business, Universitas Muhammadiyah Yogyakarta, Yogyakarta, Indonesia.

*CORRESPONDENCE:

dessyvalue@gmail.com

THIS ARTICLE IS AVALILABLE IN:

http://journal.umy.ac.id/index.php/jerss

DOI: 10.18196/jerss.040119

\section{CITATION:}

Dewi, Y. A., \& Rachmawatie, D. (2020). Poverty Analysis and Inequality Distribution in Yogyakarta Special Region. Journal of Economics Research and Social Sciences, 4(1), 59-64.

\section{Introduction}

Poverty and inequality distribution Social income has always been a phenomenon or part of a particular developing country that is developing. Poverty has also been a concern of the world, mostly since the Asian economic crisis since 1997. One form of world attention to poverty and social inequality is the contradiction of $192 \mathrm{UN}$ member states and at least 23 international organizations in 2000, for the purpose of finding the millennium goal (Development Millennium) Goals, MDGs) in 2015. In general, poverty causes the same effect on all countries, (1) welfare for poor families (clothing, food, housing). (2) the right to education, (3) the right to health, (4) the exclusion of decent work, (5) being marginalized from the right to legal protection, (6) the right to security, (7) the right to desire for government and public decisions, (8) the right to spiritual, (9) the right to innovate and more importantly (10) the right to freedom of life. Indonesia as a developing country continues to develop in the country. Development is carried out in almost every sector, both in the economic, education, health, legal, defense and other sectors. The main purpose of development itself is to improve the welfare of the community by solving existing problems, one of which is the problem of poverty. The purpose of this study is to determine poverty and inequality of income distribution that occurs in the Special Region of Yogyakarta. 


\section{Literature Review and Hypothesis Development}

Rachmawatie (2010) examined the inequality of regional development in Bogor Regency by updating the Input-Output Table and compiling the Entropy Diversity Index value between regions in Bogor Regency, the results of the study showed that based on the results of the analysis obtained with Ols, ten sectors contributed the most to gross value added in Bogor Regency. The Gross Value Added of each of these sectors are sectors: Non-oil and gas industry (66.12\%), Trade (13.79\%), LGA (3.92\%), Buildings (3.23\%), Food crops (2, 82\%), Restaurants (2.56\%), Social services (2.34\%), General Government (1.94\%), Road transport (1.73\%), and Animal Husbandry (1.54\%). In general, it can be said that the sectors that dominated the biggest contribution to gross value added (NTB) were the secondary sector (II) and the tertiary sector (III), while the primary sector (I) still made a small contribution compared to other sectors. On the other hand, based on Gross Value Added (NTB) or the GRDP produced, it turns out to be very lame, where the Non-Oil and Gas Industry (INM) sector and the trade sector are still very dominant in the economy in Bogor Regency. The total of these two sectors (non-oil and gas industry sector and trade) contributed 75.59 percent of the total NTB Bogor Regency in 2008. While other sectors only gave one to three percent of the total NTB Bogor Regency.

McCulloch and McKay in Raychaudhuri (2010), explain how the role of development in the infrastructure sector can reduce poverty by going through several stages. The definition of income inequality itself is often interpreted as a phenomenon where there is a difference or gap between the upward economic community and the downward economic community. In developing countries, the conditions that take place are the number of rich people more than poor or low income. The cause of the development imbalance, according to Kristiyanti (2007), is due to the three main factors that influence, namely natural factors, social conditions factors, and policy decisions. Natural factors include agro-climate conditions, natural resources, geographical location, port distance from the center of economic activity, geographical location, and potential areas for economic development. While socio-cultural factors include the value of tradition, economic mobility, innovation, and entrepreneurship. While policy decision factors are several policies that support directly or indirectly related to inequality.

Infrastructure relations themselves in reducing poverty levels are indirect, where there is investment in infrastructure, both from the government and the private side, will be able to affect productivity and the number of the workforce in various sectors, then the presence of adequate infrastructure will make the productivity of a sector increase so can absorb labor, which will then be followed up with economic growth and changes in salaries for the poor who then both affect the supply and price of basic goods, then the development of quality. 
Dewi \& Rachmawatie

Poverty Analysis and Inequality Distribution in Yogyakarta Special Region

\section{Result and Discussion}

\section{Discussion}

According to BPS data from the Susenas result at the end of 1998, the urban poverty line was set at Rp. 96,959 per capita per month and the rural poor population of Rp. 72,780 per capita per month. With this calculation, money can be spent to meet consumption equivalent to 2,100 calories per capita per day, plus the fulfillment of other minimum basic needs, such as clothing, health, education, transportation. This poverty line figure is very high when compared to the 1996 figure before the economic crisis, which was only around Rp. 38,246 per capita per month for urban residents and Rp. 27,413 for rural residents.

Urban poor people in the city of Yogyakarta have different characteristics from poverty in big cities like Jakarta and Surabaya. The urbanization factor as the main factor influencing it is not too large because most of the poor population are native residents and migrants who have long been residents of the place. City life that is not too frenetic also affects the social system. Some have informal work, earning an income every day. The city of Yogyakarta as a tourist destination contributes to this poverty structure because several jobs can be done as a result of tourism and the city of education. According to some poverty experts, there are at least three concepts of poverty that are often used, namely absolute poverty, relative poverty, and subjective poverty. The concept of absolute poverty is formulated by making certain concrete measurements that are generally oriented to the minimum basic living needs of community members, namely clothing, food, and housing. Meanwhile, the concept of poverty is relatively formulated by considering the dimensions of place and time. The basic assumption is that poverty in one area is different from poverty in other regions, and poverty at one time is different from poverty at another time.

The benchmarks used are based on the consideration of certain community members, oriented to the degree of the worthiness of life. Whereas the concept of subjective poverty is formulated based on the feelings of the poor themselves. Therefore, it is very likely that groups, according to certain individual sizes, are below the poverty line, but they may not consider themselves poor, and vice versa. While the group in our judgment is worth living, it may not be considered as such, and vice versa. This was felt by the majority of respondents in this study. They claimed to enjoy life, not feel the urgency. Although living in slums, cramped, and crowded, they feel comfort and happiness. The relatively calm and unhurried life of the city of Yogyakarta has influenced the feelings of the people who, in certain assessments, are categorized as poor. This was also reflected in their expectations of general government policies by taking into account the availability of facilities and targets rather than direct financial assistance due to lack of ability and employment. From the research data listed in table 6 , it is known that the poor of the city of Yogyakarta expect capital assistance to support their small businesses or to be used as initial capital to work. Percent and ease of reaching health facilities by 22 percent. While cash assistance is only 3 percent. 
Dewi \& Rachmawatie

Poverty Analysis and Inequality Distribution in Yogyakarta Special Region

Table 3 The diversity of each region/cross-section of the income distribution

\begin{tabular}{|c|c|c|c|c|c|}
\hline Rank & Region & $\begin{array}{l}\text { Individual } \\
\text { effect }\end{array}$ & Rank & Region & Individual effect \\
\hline 1 & NTB & $-0,09804$ & 18 & $\begin{array}{l}\text { Sulawesi } \\
\text { Selatan }\end{array}$ & $-0,04925$ \\
\hline 2 & DKI Jakarta & $-0,09736$ & 19 & Jambi & $-0,04903$ \\
\hline 3 & Maluku & $-0,0899$ & 20 & $\begin{array}{l}\text { Sumatera } \\
\text { Selatan }\end{array}$ & $-0,04871$ \\
\hline 4 & NTT & $-0,0822$ & 21 & $\begin{array}{l}\text { Sulawesi } \\
\text { Barat }\end{array}$ & $-0,04769$ \\
\hline 5 & Papua Barat & $-0,07295$ & 22 & $\begin{array}{l}\text { Sulawesi } \\
\text { Tengah }\end{array}$ & $-0,04583$ \\
\hline 6 & Bengkulu & $-0,07057$ & 23 & $\begin{array}{l}\text { Kalimantan } \\
\text { Barat }\end{array}$ & $-0,04366$ \\
\hline 7 & $\begin{array}{l}\text { Sulawesi } \\
\text { Utara }\end{array}$ & $-0,06682$ & 24 & Jawa Tengah & $-0,04346$ \\
\hline 8 & NAD & $-0,06676$ & 25 & Maluku Utara & $-0,04195$ \\
\hline 9 & $\begin{array}{l}\text { DIY } \\
\text { Yogyakarta }\end{array}$ & $-0,06253$ & 26 & $\begin{array}{l}\text { Kalimantan } \\
\text { Tengah }\end{array}$ & $-0,0405$ \\
\hline 10 & Gorontalo & $-0,05983$ & 27 & $\begin{array}{l}\text { Sumatera } \\
\text { Utara }\end{array}$ & $-0,0401$ \\
\hline 11 & $\begin{array}{l}\text { Sulawesi } \\
\text { Tenggara }\end{array}$ & $-0,05801$ & 28 & $\begin{array}{l}\text { Bangka } \\
\text { Belitung }\end{array}$ & $-0,03969$ \\
\hline 12 & Jawa Timur & $-0,05228$ & 29 & $\begin{array}{l}\text { Kalimantan } \\
\text { Timur }\end{array}$ & $-0,03674$ \\
\hline 13 & Bali & $-0,05082$ & 30 & Lampung & $-0,03501$ \\
\hline 14 & $\begin{array}{l}\text { Kalimantan } \\
\text { Selatan }\end{array}$ & $-0,04997$ & 31 & Jawa Barat & $-0,03366$ \\
\hline 15 & Riau & $-0,0498$ & 32 & $\begin{array}{l}\text { Kepulauan } \\
\text { Riau }\end{array}$ & $-0,03336$ \\
\hline 16 & Banten & $-0,04975$ & 33 & Papua & 0,09373 \\
\hline 17 & & \multicolumn{2}{|c|}{ Sumatera Barat } & $-0,04957$ & \\
\hline
\end{tabular}

Based on the results table individual effects can show individual effects in each province, where the entire province has a negative value, which can be interpreted if this model is applied it is expected to reduce the level of income inequality in Indonesia's provinces. This province is the 9th most populated region of this research model, allegedly because this province has a high level of inequality, but has an economic structure dominated by agriculture and services, even the industrial sector is less developed compared to the other two sectors so that if investment is encouraged in the agriculture and services sectors, it is likely to be influential to reducing the level of income inequality. But the industrial sector must not be forgotten. The second suggestion for this region is to synergize the three sectors based on the agricultural sector. Continuing capital spending in this region is quite low, but if added, it will be able to reduce the level of disagreement, so the third suggestion in this region is increasing the portion of capital expenditure that is more allocated to road infrastructure. 


\section{The Policy Response of Yogyakarta Government}

One of the critical success factors in handling poverty and other social problems such as unemployment is by reviewing policies and programs that have been implemented so far. Today the Central Government has poured trillions of rupiah into poverty to reduce poverty in various parts of the region and make it a development priority. This was also followed by the Regions, including the City of Yogyakarta. By mapping and reviewing the policies implemented, it is hoped that programs will be obtained, which are still feasible to be continued, evaluated, and new programs as a breakthrough or therapy for the poor.

The government's policy response is a poverty reduction program that has been carried out by the Yogyakarta city government to overcome poverty in its region. The prevention program is related to anti-poverty strategies. This analysis uses a qualitative descriptive technique by describing data from the document review results following the related variables. The policies analyzed consist of poverty alleviation programs implemented in the city of Yogyakarta. Government policies come from the central government and regional governments. This research does not identify which of the two policies.

\section{Conclusion}

The phenomenon of poverty and unemployment in Indonesia, including the city of Yogyakarta, is a complex phenomenon and cannot be easily seen from one absolute number. The city of Yogyakarta, known as a student city and tourist city, along with the development of the city, has a strong appeal to urbanization that feels the presence of the government. The next policy should be more detailed and specific because Yogyakarta City poverty is not too prominent both in terms of its economy and social structure. The Yogyakarta City Government only needs to personally identify poor households so that they can assist more precisely, and the Social Service as an example can do this.

DIY Province is the 9th resident of this research model, allegedly because this province has a high level of inequality, but has an economic structure dominated by agriculture and services, even the industrial sector is less developed compared to the other two sectors so that if investment is encouraged in the agriculture and services sectors, it is likely to be influential about reducing the level of income inequality. But the industrial sector must not be forgotten; the second suggestion for this region is to synergize the three sectors based on the agricultural sector. Continuing capital spending in this region is quite low, but if added, it will be able to reduce the level of disagreement, so the third suggestion in this region is increasing the portion of capital expenditure that is more allocated to road infrastructure. 


\section{References}

Bratakusuma, S. (2003). Regional Planning Development. .Jakarta: Penerbit PT. Gramedia Pustaka Utama.

Datt, G., \& Ravallion, M. (1998). Why The Indian States Have done Better Than Others and Reducing Poverty. Economica. 65; 257.

Kristiyanti, L. (2007). Economic Base Sector Analysis and Its Role in Reducing Income Inequality between Regencies / Cities in East Java Province). Journal of Economics. IPB University. Bogor.

Nangarumba, M. (2015). Analisis pengaruh struktur ekonomi, upah minimum provinsi, belanja modal, dan investasi terhadap ketimpangan pendapatan di seluruh provinsi di indonesia tahun 2005-2014. Jurnal Ekonomi dan Studi Pembangunan, 7(2). Retrieved from http://journal.um.ac.id/index.php/jesp/article/view/5326/1978

Pontoh \& Kustiwan, I. (2009). Introduction to Urban Planning. Institut Teknologi Bandung. ITB. Bandung.

Prawoto, N. (2008). Memahami Kemiskinan dan Strategi Penanggulangannya. Jurnal Ekonomi \& Studi Pembangunan, 9(1).

http://journal.umy.ac.id/index.php/esp/article/view/1530/1578

Rachmawatie, D. (2010). Analysis of Inequality Development in Bogor Regency. Thesis. IPB University. Post Graduate School. Bogor.

Rayhchaudhuri, A. (2010). Inequality in Trade, Infrastructure, and Income in Selected Asian Countries: An Empirical Analysis. Asia-Pacific Research and Training Network for the Trade Working Paper Series, No. 82. 